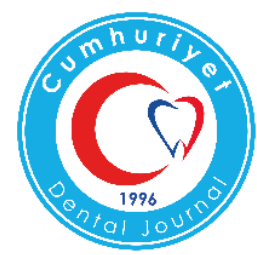

\title{
EFFECTS OF PROPOLIS ON OXIDATIVE STRESS IN RABBITS UNDERGOING IMPLANT SURGERY
}

\author{
Implant Cerrahisi Uygulanan Tavşanlarda Propolisin Oksidatif Stres Üzerine \\ Etkisi
}

Ezgi AYDIN ${ }^{1}$, Ceylan HEPOKUR ${ }^{2}$, Sema MISIR ${ }^{2}$, Hasan YELER ${ }^{1}$

\author{
Makale Kodu/Article Code $\quad$ : 356554 \\ Makale Gönderilme Tarihi $\quad: 20.11 .2017$ \\ Kabul Tarihi \\ $: 16.03 .2018$
}

\section{ABSTRACT}

Objectives: Dental implant is the reconstructive material that supports prosthetic restoration when one or more teeth is missing. Bone healing around the implant and factors that affect the bone healing affects osseointegration. Recent studies show that, free radicals are among the factors that affect the bone healing. Propolis has an antioxidant nature and effects on accelerating the bone formation, wound healing and increasing the bone density. This study is planned presuming propolis could have a positive effect on healing by reducing the free radical levels through antioxidant activity after implantation.

Materials and Methods: 24 New Zealand white rabbits were used in the study. Animals were divided into 3 groups, each consisting of 8 rabbits. In all groups, implants were placed into the proximal region of tibia unilaterally. In the control group, only the dental implant was placed in the prepared slot. Propolis solution [dissolved in dimethyl sulfoxide (DMSO) and diluted with saline] was applied to slots before placing the implants on local group. In the systemic group, propolis solution was given to rabbits every day after implantation by oral gavage. Before sacrificing the rabbits on $28^{\text {th }}$ day, $5 \mathrm{cc}$ of blood was taken from each rabbit to investigate Vitamin D, calcium, phosphor and antioxidant enzyme values.

Results: SOD (superoxide dismutase) activity was increased in both propolis groups compared to control group, but it was not statistically significant. Catalase level of the systemic group was found to be significantly higher. MDA (malondialdehyde)

level in serum, which indicates lipid peroxidation, was significantly lower in both propolis groups compared to control group. Reduced GSH (glutathione) concentration in granulation tissue was increased in rabbit groups treated with propolis compared to control group. There were no significant differences in calcium and phosphorus values, however it can be said that there is a significant increase in vitamin D amount of local and systemic groups.

Conclusion: Changes in CAT, GPx and MDA levels in propolis treated groups indicate that propolis reduces oxidative stress. Observation of an increase in the level of vitamin D shows better healing of the implanted bones (especially with systemic administration) when propolis was administered.

Key Words: implant, antioxidant activity, propolis

\section{öz}

Giriş: Dental implant eksik bir veya birden fazla dişin rekonstrüksiyonunda protetik restorasyona destek olan yap1 için kullanılan ifadedir. İmplant çevresinde gerçekleşen kemik iyileşmesi ve kemik iyileşmesine etki eden faktörler osseointegrasyonu etkiler. Son yıllarda yapılan çalışmalar, kemik iyileşmesi üzerine etkili olan faktörler arasında serbest radikallerin de bulunduğunu göstermektedir. Propolisin antioksidan, kemik formasyonunu ve yara iyileşmesini hızlandırıcı, ayrıca kemik densitesini arttırıcı etkisi bulunmaktadır. Bu çalışma propolisin, implant uygulaması sonrası antioksidan aktivitesi sayesinde serbest radikal oranını azaltarak, iyileşmeye olumlu etki edebileceği düşünülerek planlanmıştır.

Materyal ve Metot: Çalışmada toplam 24 adet Yeni Zelanda tavşanı kullanılmıştır. Çalışma 8'er tavşan içeren 3 gruptan oluşmuştur. Tüm gruplarda implantlar tibia proksimal metafiz bölgesine unilateral olarak yerleştirilmiştir. Kontrol grubunda hazırlanan yuvaya sadece dental implant yerleştirilmiştir. Lokal grupta hazırlanan yuvaya solüsyon halindeki propolis [dimetilsülfoksitte çözülmüş (DMSO) ve serum fizyolojik ile seyreltilmiş] uygulanarak dental implant yerleştirilmiştir. Sistemik grupta ise implantasyon sonrası her gün tavşanlara propolis solüsyonu oral gavaj ile verilmiştir. Deneyin 28. gününde, sakrifikasyondan önce tavşanlardan 5'er cc kan alınarak vitamin D, kalsiyum, fosfor ve antioksidan enzim seviyeleri ölçülmüştür.

Bulgular: Her iki propolis grubunda da kontrol grubuna göre SOD (süperoksit dismutaz) aktivitesinde artış görülmüştür, ancak bu artış istatistiksel olarak anlamlı değildir. Sistemik grubun CAT (katalaz) seviyesi önemli derecede yüksek bulunmuştur. Lipid peroksidasyonunu gösteren serumdaki MDA (malondialdehit) seviyesi, her iki propolis grubunda kontrol grubuna göre anlamlı derecede düşük izlenmiştir. Granülasyon dokusundaki azalmış GSH (glutatyon) konsantrasyonu propolis uygulanan gruplarda kontrol grubuna kıyasla artmış bulunmuştur. Kalsiyum ve fosfor değerlerinde önemli bir farklılık bulunmamakla birlikte, lokal ve sistemik grupta D vitamininde belirgin bir artış olduğu görülmüştür.

Sonuç: Propolis uygulanan gruplardaki CAT, GSH ve MDA düzeylerindeki değişiklikler propolisin oksidatif stresi azalttığını gösterir. D vitamini seviyesinde artış izlenmesiyle de implante edilen kemikler arasında propolis uygulananlarda (özellikle sistemik uygulama ile) iyileşmenin daha iyi olduğu sonucuna varılmıştır.

Anahtar Kelimeler: implant, antioksidant aktivite, propolis 


\section{INTRODUCTION}

In modern dentistry, dental implant is considered as oe of the most popular and common treatment options for edentulous patients. Implant insertion requires bone preparation, and occasional flap and bone graft application. ${ }^{1}$ These may cause ischemia in tissues $^{2}$ and acute inflammation ${ }^{3,4}$ that may lead to an increase in oxidative stress levels. When implant or prosthetic restoration causes problems and interrupts the patient's prognosis or normal use, implant related complications arise. $^{5}$ Recently, researchers started to show interest to the idea that complications of implants may be a result of the free-radical induced tissue damage. ${ }^{1-3}$

In oxidative processes, reactive oxygen species (ROS) are formed in all cells and tissues within normal cell cycle but occuring at relatively low levels. ${ }^{6,7}$ The production of ROS like superoxide, hydrogen peroxide and hydroxyl radical etc., which are primarily formed by mitochondria within normal cellular metabolism, increases with inflammation. ${ }^{8}$ In the early phases of regenerative processes, inflammation is necessary to initiate the repair cascade. However, inflammatory response should end for starting tissue regeneration, so that healing may take place naturally. If inflammatory response does not cease, and it turns to be a chronic inflammation due to infection, then bone formation is likely to be affected from it. The risk of chronic infection may be higher if there is a material or device implanted into the surgical site due to a potential microbial colonization. ${ }^{9}$ Chronic inflammation exerts its cellular side effects mainly through excessive production of free radicals and depletion of antioxidants. ${ }^{10}$

Recent culture studies showed that some currently available biomaterials, cause biologically adverse effects on several cell types. For example, titanium alloy damages osteoblasts by activating macrophages and the monocytes ${ }^{11}$, hydroxylapatite particles increase the inflammatory cytokine production in osteoblasts after contact ${ }^{12}$ and so on. The occurrence of these adverse cellular reactions due to biomaterials is suggested to be associated with excessive production of intracellular ROS, resulting in higher oxidative stress levels, although this remains to be confirmed. ${ }^{13,14}$ To neutralize the negative effects of free radicals on tissues and cells, a wide variety of antioxidant and repair mechanisms has been evolved. ${ }^{15}$ Cells contain enzymes, such as superoxide dismutase (SOD), glutathione peroxidase (GPx) and catalase (CAT), to overcome potential tissue damaging effects of ROS. These enzymes are important antioxidant components of several naturally-occurring defense mechanisms that prevent oxidative deformation. $^{7}$

Propolis is a resinous material which honeybees gather from the bark and buds of certain types of plants and trees. Propolis is a highly complex mixture of natural components. It contains amino acids, phenolic acids, phenolic acid esters, cinnamic acid, terpenes, flavonoids, caffeic acid etc. ${ }^{16}$ Propolis has been found to have anti-inflammatory, anti-oxidant, anti-bacterial, anti-tumor and also anesthetic and analgesic activities. ${ }^{17,18}$ Biological effects of propolis, which is rich in flavonoids, aroused the need of conducting studies about propolis, in many fields. There are many studies about the use of propolis in oral health. ${ }^{19}$ Propolis affects different pathogenic microorganisms in the mouth, such as, bacteria, fungi and viruses, moreover it can be successfully applied in different dental diseases, such as mouth sores and ulcers, and gingivitis. ${ }^{19}$ However, at the end of our literature review, we did not encounter any scientific studies investigating the effects of propolis on oxidative stress after implantation process.

The aim of this study is to evaluate the effects of propolis on oxidative stress and bone healing considering it has antioxidant effects and it enhances wound healing, bone formation, as well as bone density. ${ }^{20}$ 


\section{MATERIALS AND METHODS}

This study was approved by the Cumhuriyet University Ethics Committee for the animal care and use, with the number 65202830050.04.04.

\section{Preparation of the Propolis}

$1 \mathrm{~g}$ of propolis (Eğriçayır Organic Bee Products / Mersin) was added to $1 \mathrm{ml}$ dimethyl sulfoxide (DMSO) and vortexed for 1 minute (Jeio Tech, Vortex Mixer VM-96T). The prepared mixture was put in an ultrasonic bath (Kudos HP Heating Series ultrasonic cleaner) and stirred at $25{ }^{\circ} \mathrm{C}$ and $53 \mathrm{kHz}$, for 15 minutes. After filtering via sterile filters with $0.22 \mu \mathrm{m}$ pore size, prepared solution was diluted with saline (1: 4; DMSO: saline) and get ready to use.

\section{Experimental Diet and Design of Animals}

Experiments were performed at Cumhuriyet University, Faculty of Medicine and animal research laboratory. Our study was conducted with 24 male, white, New Zealand rabbits, approximately 5 months-old and weighed around 2.7 to $3.0 \mathrm{~kg}$. Rabbits were kept in standard cages at $22-24^{\circ} \mathrm{C}, 55-70 \%$ humidity, 1 atm pressure and under $12 \mathrm{~h}$ of artificial lighting. For the adaptation of the rabbits to laboratory environment, they were placed in the cages 2 weeks prior to experiment and their health were monitored continuously. Animals were divided into 3 groups, each consisting of 8 rabbits.

\section{Implantation of the biomaterials}

Implants were placed into the proximal region of tibia unilaterally. The selected dental implant had external hexagonal platform; it was $3.5 \mathrm{~mm}$ in diameter and $10 \mathrm{~mm}$ in length [ADIN Dental Implant Systems (SLA Surface, Toureg-NP, Afula, Israel)]. For the insertion of the implants, all animals went under anesthesia via 10-20 $\mathrm{mg} / \mathrm{kg}$ Xylazine (Rompin 2\%, Bayer, Istanbul, Turkey) and $90 \mathrm{mg} / \mathrm{kg}$ of ketamine $\mathrm{HCl}$ (Ketan's Eczacıbaş1-Warner Lambert, Istanbul, Turkey). General anesthesia was performed by intramuscular injection to animals that starved preoperatively. Unilateral tibia proximal region was shaved and following the intramuscular injections of prophylactic antibiotics $(50 \mathrm{mg} / \mathrm{kg}$ ceftriaxone) and analgesics (4 $\mathrm{mg} / \mathrm{kg}$ Carprofen) antiseptic solution was applied. Surgical area was prepared by coating with sterile surgical drapes and sterile film. Followed by blunt dissection and elevating subcutaneous and muscle layers, the skin was incised for 2 $\mathrm{cm}$, extending distally from the proximal tibia metaphysis. After periosteal incision with a scalpel, tibia surface was reached. Paying attention to have at least $6 \mathrm{~mm}$ thickness on the exposed bone at the proximal metaphyseal bone platform, implant socket was prepared being perpendicular to the surface. Implant slot was prepared as suggested by the manufacturer, under adequate saline irrigation and using the burs at 600-1000 rpm until the sufficient width and length was obtained. Then dental implants were placed into the slots.

Control Group: The slots were prepared as described above, dental implants were placed in the slots without any further treatment.

Local Group: The slots were prepared as described above, propolis solution [dissolved in dimethyl sulfoxide (DMSO) and diluted with saline] was applied to the slots and then dental implants were placed.

Systemic Group: The slots were prepared as described above, dental implants were placed, and propolis was applied to rabbits systemically by oral gavage.

Implantation process of all groups was completed by placing the implants into the slots using a ratchet. After the operation, elevated epidermal flap was sutured to its original position, starting with the muscles, and continuing with the subcutaneous fascia and skin using the suture 5-0 polyglactin 910 (Vicryl Jonson \& Johnson/Ethicon). $50 \mathrm{mg} / \mathrm{kg}$ ceftriaxone (Cephaxon-Toprak) IM and 4 $\mathrm{mg} / \mathrm{kg}$ Carprofen (Rimadyl- Pfizer) subcutaneously from $20 \mathrm{cc}$ vial was given to animals for 3 days after the operation. $200 \mathrm{mg}$ / 
$\mathrm{kg} / \mathrm{day}$ of the propolis was given to the rabbits of Systemic Group by oral gavage for 28 days. All animals were sacrificed using $200 \mathrm{mg} / \mathrm{kg}$ sodium pentobarbital intraperitoneally on $28^{\text {th }}$ day.

\section{Biochemical Tests}

Before sacrificing the animals, $5 \mathrm{cc}$ of blood was taken from the heart of each rabbit into biochemical tubes. Serum was obtained by centrifuging them for $10 \mathrm{~min}$ at $4000 \mathrm{rpm}$. Vitamin D, calcium, and phosphor values of the serum samples were analyzed at biochemistry laboratory of Faculty of Medicine with an auto analyzer. Then the results were interpreted in terms of the effect of propolis on antioxidant system and bone healing process after implantation.

Determination of MDA: Procedure defined by Yagi K. ${ }^{21}$ was used for the MDA measurement. Evaluation of the absorbance of the color that MDA forms with thiobarbituric acid (TBA) in acidic media at $532 \mathrm{~nm}$, provides the essence of this procedure. $300 \mu \mathrm{L}$ of $10 \%$ phosphotungstic acid and $2.4 \mathrm{~mL}$ of $0,084 \mathrm{M}$ sulfuric acid solutions were measured and adjoined with 300 $\mu \mathrm{L}$ of serum sample before incubating for 45 minutes at $95^{\circ} \mathrm{C}$. Samples were cooled for the evaluation of the absorbance at $532 \mathrm{~nm}$. These results formed the basis for the graph of the standard. MDA findings were analyzed according to this graph.

Determination of SOD activity: Procedure defined by Sun et $a l^{22}$ was used for the measurement of superoxide dismutase (SOD) activity in the serum taken from the rabbits. Forming the formazan by reducing colorants, which are formed during the oxidation of xanthine oxidase $(\mathrm{XO})$ with xanthine, like nitro blue tetrazolium (NBT), is the basis of this procedure. Composed NBT is based on the spectrophotometric evaluation of the absorbance of the color at $560 \mathrm{~nm}$.

Determination of Catalase activity: Procedure defined by Aebi's ${ }^{23}$ was used to measure catalase activity. $50 \mathrm{mM}$ phosphate buffer with $\mathrm{pH} 7.0$ and $30 \mathrm{mM}$ hydrogen peroxide $\left(\mathrm{H}_{2} \mathrm{O}_{2}\right)$ solution was prepared. $1 \mathrm{~mL}$ of $\mathrm{H}_{2} \mathrm{O}_{2}$ solution, $2 \mathrm{~mL}$ of sample and $1 \mathrm{~mL}$ of phosphate buffer was mixed and measurements were made at $230 \mathrm{~nm}$.

Determination of GSH-Px activity: Procedure defined by Paglie and Valantine ${ }^{24}$ was used to measure catalytic activity. The reduction of NADPH's absorbance was observed at $340 \mathrm{~nm}$ and regulated kinetically.

The results were analyzed using one-way variance analysis (ANOVA) with post hoc Scheffe's test. P-values $<0.05$ were taken for statistical significance.

\section{RESULTS}

In our study, oxidative stress parameters GPx, Cat, SOD activity and MDA were measured in order to evaluate the amount of ROS found in serum samples taken from the rabbits after propolis treatment.

SOD activity was increased in both propolis groups compared to control group, but it was not statistically significant $(\mathrm{p}>0.05)$ (Fig1).

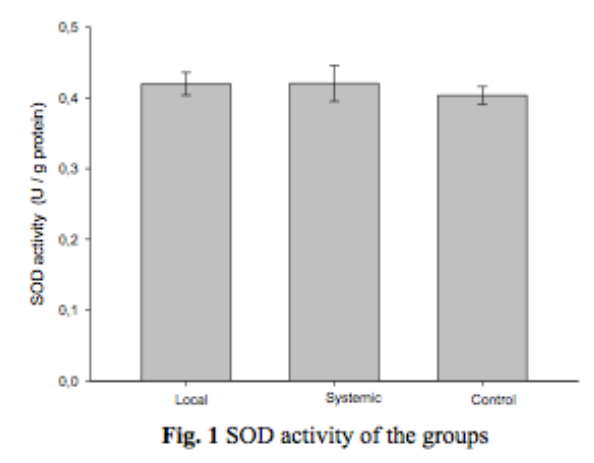

SOD levels were $0,4196 \mathrm{U} / \mathrm{g}$ protein for Local Group group, 0,4205 U/g protein for Systemic Group group and $0,4034 \mathrm{U} / \mathrm{g}$ protein for control group.

Figure 1. Effects of propolis on antioxidant enzyme activity. There is no significant difference in SOD activities between the control 
and experimental groups. ( $\mathrm{p}>0.05, \mathrm{n}=8$ for each group).

Catalase level of the systemic group was found to be significantly higher ( $\mathrm{p}<0.05)$ (Fig. 2).

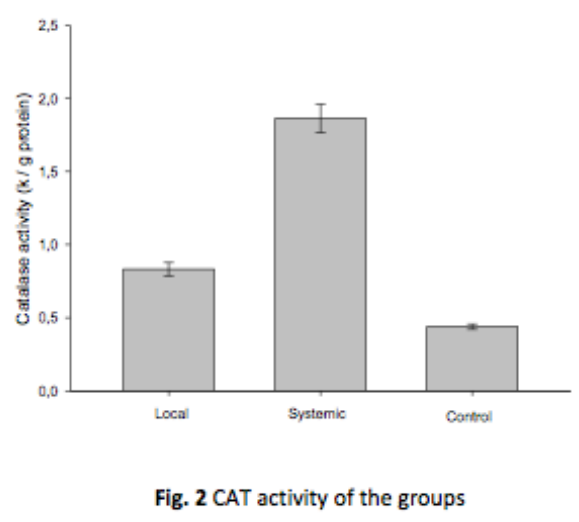

Cat levels were $0,8320 \mathrm{k} / \mathrm{g}$ protein for Local Group group, $1,8633 \mathrm{k} / \mathrm{g}$ protein for Systemic Group group and $0,4390 \mathrm{k} / \mathrm{g}$ protein for control group.

Figure 2. Effects of propolis on Catalase level. Catalase level was significantly increased in Systemic Group compared to other groups. ( $\mathrm{p}<0.05, \mathrm{n}=8$ for each group).

Malondialdehyde (MDA) level in serum, which indicates lipid peroxidation, was significantly lower in both propolis groups compared to control group ( $<<0.05)$ (Fig. 3).

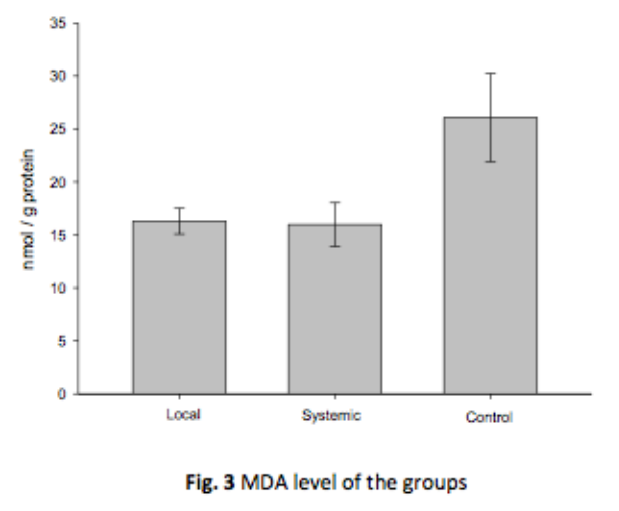

MDA levels were $16,2883 \mathrm{nmol} / \mathrm{mg}$ protein for Local Group group, 15,9766 $\mathrm{nmol} / \mathrm{mg}$ protein for Systemic Group group and $26,0676 \mathrm{nmol} / \mathrm{mg}$ protein for control group.

Figure 3. Effects of propolis on on MDA level. MDA level was significantly decreased in both propolis groups compared to control group ( $\mathrm{p}<0.05, \mathrm{n}=8$ for each group).

Reduced GSH concentration in granulation tissue was increased in rabbit groups treated with propolis compared to control group. A significant increase was observed in the GSH level of treated group compared to control group (p<0.05) (Fig. 4).

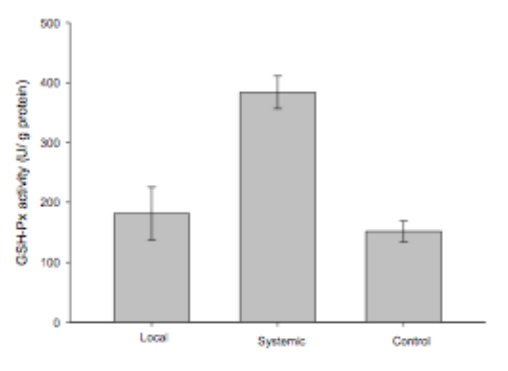

Fig. 4 Glutathione peroxidase activity of the groups

GSH-Px levels were 181,0928 U/g protein for Local Group group, 383,6860 U/g protein for Systemic Group group and 151,6390 U/g protein for control group.

Figure 4. Effects of propolis on GSH-Px level. Both propolis groups showed a significant increase compared to the control group. $(\mathrm{p}<0.05, \mathrm{n}=8$ for each group).

There were no significant differences in calcium and phosphorus values, however it can be said that there is a significant increase in vitamin $\mathrm{D}$ level of local and systemic groups $(\mathrm{p}<0.05)($ Table 1).

Table 1 Results of Biochemical Tests

\begin{tabular}{llll}
\hline & Vitamin D & Calcium & Phosphorus \\
\hline LOCAL & $44,09 \pm 5,86$ & $13,38 \pm 0,97$ & $6,98 \pm 0,71$ \\
SYSTEMIC & $64,6 \pm 4,4$ & $14,09 \pm 0,96$ & $5,86 \pm 0,87$ \\
CONTROL & $35,02 \pm 4,71$ & $13,78 \pm 0,58$ & $5,76 \pm 0,67$ \\
\hline & $P<0.05$ & $P>0.05$ & $P>0.05$
\end{tabular}

Table 1. Biochemical analysis of in serum samples taken from the rabbits after propolis treatment for each group 


\section{DISCUSSION}

Dental implant treatment is a reliable technique, which produces effective results. ${ }^{4,11,19}$ However, researchers are still in need of ways to improve implantation in order to achieve the optimal osseointegration faster and to ensure optimal healing on poor bone quality and quantity. There are many local and general factors that have positive or negative impacts on bone healing. Recent studies showed that free radicals are also among the factors that effects bone healing. There are studies reporting the formation of free radicals in the early recovery period, where the most intense biological interactions are observed, and indicating that these radicals have negative effects on bone healing. ${ }^{1-3}$

There are many important factors that should be considered for achieving a successful osseointegration, including the primary stability and surface properties of the implant, anatomical conditions of the implanted site, design of the prosthesis, the occlusion pattern during the healing phase and the bone metabolism ${ }^{1}$. Oxidative stress is among the factors that affect bone healing. ${ }^{25}$

Propolis accelerates the healing of bone fracture and increases the quality of the bone. It has been shown that propolis increases bone mineral content, bone density and volume, accelerates bone formation and shorten the consolidation phase in the rabbits to whom distraction osteogenesis was applied. ${ }^{16}$

Ozmen et al showed that experimental implantation is accompanied by increased lipid peroxidation (LP) in rats. Also, GPx, CAT and SOD in the tissues surrounding ceramic and titanium implants decreased. Results suggested that the measurement of antioxidant enzymes and LP may be a predictor of implant-induced tissue injury. And oxidative stress may have an important role on tissue pathophysiology induced by ceramic and titanium implantation. ${ }^{26}$
Enhanced osteoclastic activity observed in bone disorders may have been responsible for increased production of ROS in form of superoxide, which is evident by increased levels of serum MDA levels. One of the most damaging effects of ROS is lipid peroxidation, the end product of which is MDA. ${ }^{25}$ MDA in addition to serving as an index of lipid peroxidation has also served as a measure of osteoclastic activity. Depressed activities of the antioxidant enzymes, SOD and GSH-PX illustrated a defense mechanism that may have been overwhelmed in mitigating the increased superoxide production by the osteoclasts represented by increased levels of MDA in the serum. ${ }^{25}$ Higher vitamin D intake is recognized to be necessary to keep not only bone health but also muscle strength. ${ }^{27}$

Many researchers, using different types of assays, reported that propolis has in-vitro antioxidant activity. Antioxidant activity of propolis is partly related with its radical scavenging properties and with high phenols content of resin. Antioxidant enzyme activities such as SOD and CAT may sometimes decrease under stimulation of lipid peroxidation ${ }^{28}$ or increase. $^{29}$

In this study, no significant change was observed on SOD whereas CAT level of systemic group was significantly increased. Regarding GPx, a significant increase occurred is systemic group compared to control group.

In our study, MDA level of both propolis groups were found to be significantly lower than control group, which shows that propolis reduces oxidative stress. The difference between systemically and locally applied propolis is not significant.

The study of Nieva et al. conducted with Argentina propolis showed that there is a correlation between antioxidant activity and flavonoid content. ${ }^{30}$ They have also reported that there is a positive relationship between flavonoid content and the percentage of inhibited malondialdehyde (MDA). ${ }^{31}$ 
Koksel et al. reported that CAPE, which is one of the main components of propolis, significantly decreased MDA levels, inflammation and lung tissue damage that is caused by LPS. ${ }^{32}$ Hoşnuter et al. reported that CAPE reduced MDA level by suppressing lipid peroxidation, showed antioxidant property by preventing the formation of reactive oxygen species. ${ }^{33}$

It has been shown that propolis and its polyphenolic compounds increases GSH-Px, GSSG-R, SOD, CAT, XO, iNOS activities of enzymatic antioxidants, whereas in nonenzymatic environment they increase GSH level and protect DNA from hydrogen peroxide, singlet oxygen molecules and hydrated electron attacks. ${ }^{34}$ There was no significant difference in terms of SOD activity between propolis groups and control groups.

In our study no significant difference was observed in calcium and phosphorus values, however a significand increase occurred in the amount of vitamin D in propolis groups compared to the control group. Therefore, we can conclude that among the implant applied bones, the healing of the ones treated with propolis (especially systemically) was better.

\section{CONCLUSION}

Propolis is a bee product that has many biological activities such as antioxidant, and antimicrobial. Owing to these features, propolis has a positive effect on osseointegration and bone healing. The comparison of systemic and local group showed that, systemically given propolis provided better results

\section{REFERENCES}

1. Li, S., Yang, Y., Yu, C., Yao, Y., Wu, Y., Qian, L., \& Cheung, C. W. (2015). Dexmedetomidine analgesia effects in patients undergoing dental implant surgery and its impact on postoperative inflammatory and oxidative stress. Oxidative medicine and cellular longevity.
2. Gvetadze, R., Krechina, E. K., Abramian, S. V., Ivanov, A. A., \& Nubarian, A. P. (2013). Study of blood circulation microdynamics in gingival mucosa after dental implantation with the use of custom-made healing abutments. Stomatologiia, 92(3), 109.

3. Vlahovic, Z., Markovic, A., Golubovic, M., Scepanovic, M., Kalanovic, M., \& Djinic, A. (2015). Histopathological comparative analysis of peri-implant soft tissue response after dental implant placement with flap and flapless surgical technique. Experimental study in pigs. Clinical oral implants research, 26(11), 1309-1314.

4. Figueiredo, A., Coimbra, P., Cabrita, A., Guerra, F., \& Figueiredo, M. (2013). Comparison of a xenogeneic and an alloplastic material used in dental implants in terms of physico-chemical characteristics and in vivo inflammatory response. Materials Science and Engineering: C, 33(6), 3506-3513.

5. Malet J., Mora F. \& Bouchard P. (2012) Implant Dentistry at a Glance. WileyBlackwell; $144 \mathrm{p}$.

6. Kökçam I., Nazıroğlu M. (2002). Effects of vitamin $\mathrm{E}$ supplementation on blood antioxidants levels in patients with Behçet's disease. Clinical biochemistry, 35(8), 633-639.

7. Gul M., Kutay F. Z., Temocin S., Hanninen O. (2000). Cellular and clinical implications of glutathione.

8. Sato N., Ueno T., Kubo K., Suzuki T., Tsukimura N., Att W., Ogawa, T. (2009). NAcetyl cysteine (NAC) inhibits proliferation, collagen gene transcription, and redox stress in rat palatal mucosal cells. dental materials, 25(12), 1532-1540.

9. Thomas, M. V., Puleo D. A. (2011). Infection, inflammation, and bone regeneration: a paradoxical relationship. Journal of dental research, 90(9), 1052-1061.

10.Hold G. L., El-Omar M. E. (2008). Genetic aspects of inflammation and cancer. Biochemical Journal, 410(2), 225-235.

11.Kalbacova M., Roessler S., Hempel U., Tsaryk R., Peters K., Scharnweber D., Dieter P. 
(2007). The effect of electrochemically simulated titanium cathodic corrosion products on ROS production and metabolic activity of osteoblasts and monocytes/macrophages. Biomaterials, 28(22), 3263-3272.

12.Lenz R., Mittelmeier W., Hansmann D., Brem R., Diehl P., Fritsche A., Bader R. (2009). Response of human osteoblasts exposed to wear particles generated at the interface of total hip stems and bone cement. Journal of Biomedical Materials Research Part A, 89(2), 370-378.

13. Tsaryk R., Kalbacova M., Hempel U., Scharnweber D., Unger R. E., Dieter P., Peters K. (2007). Response of human endothelial cells to oxidative stress on Ti6Al4V alloy. Biomaterials, 28(5), 806-813.

14. Tsukimura N., Yamada M., Aita H., Hori N., Yoshino F., Lee M. C. I., Ogawa T. (2009). Nacetyl cysteine (NAC)-mediated detoxification and functionalization of poly (methyl methacrylate) bone cement. Biomaterials, 30(20), 3378-3389.

15.Khansari N., Shakiba Y., Mahmoudi M. (2009). Chronic inflammation and oxidative stress as a major cause of age-related diseases and cancer. Recent patents on inflammation \& allergy drug discovery, 3(1), 73-80.

16. Bereket C., Özan F., Sener I., Tek M., Altunkaynak B. Z., Semirgin S. U., Özdemir, M. (2014). Propolis accelerates the consolidation phase in distraction osteogenesis. Journal of Craniofacial Surgery, 25(5), 1912-1916.

17.Bankova V. (2005). Recent trends and important developments in propolis research. Evidence-based complementary and alternative medicine, 2(1), 29-32.

18. Banskota A. H., Tezuka Y., \& Kadota S. (2001). Recent progress in pharmacological research of propolis. Phytotherapy Research, 15(7), 561-571.

19.Bogdanov S (2012) Propolis composition healthy medicine a review bee product science; www.bee-hexagon.net.

20.Guney A., Karaman I., Oner M., Yerer M. B. (2011). Effects of propolis on fracture healing: an experimental study. Phytotherapy Research, 25(11), 1648-1652.

21.Yu L. W., Latriano L., Duncan S., Hartwick R. A., Witz G. (1986). High-performance liquid chromatography analysis of the thiobarbituric acid adducts of malonaldehyde and trans, transmuconaldehyde. Analytical biochemistry, 156(2), 326-333.

22.Sun Y. I., Oberley L. W., Li, Y. (1988). A simple method for clinical assay of superoxide dismutase. Clinical chemistry, 34(3), 497-500.

23.Aebi H. E., (1983) Catalase. Methods of Enzymatic Analysis, 3, 273-286.

24.Paglia D. E., Valentine W. N. (1967). Studies on the quantitative and qualitative characterization of erythrocyte glutathione peroxidase. The Journal of laboratory and clinical medicine, 70(1), 158-169.

25.Sheweita S. A., Khoshhal K. I. (2007). Calcium metabolism and oxidative stress in bone fractures: role of antioxidants. Current drug metabolism, 8(5), 519-525.

26. Ozmen I., Naziroglu M., Okutan, R. (2006). Comparative study of antioxidant enzymes in tissues surrounding implant in rabbits. Cell biochemistry and function, 24(3), 275-281.

27.Södergren E., Cederberg J., Basu S., Vessby B. (2000). Vitamin E supplementation decreases basal levels of F2-isoprostanes and prostaglandin F2 $\alpha$ in rats. The Journal of nutrition, 130(1), 10-14.

28.Wohaieb S. A., Godin D. V. (1987). Alterations in tissue antioxidant systems in the spontaneously diabetic (BB Wistar) rat. Canadian journal of physiology and pharmacology, 65(11), 2191-2195.

29. Aliciguzel Y., Ozen I., Aslan M., Karayalcin U. (2003). Activities of xanthine oxidoreductase and antioxidant enzymes in different tissues of diabetic rats. Journal of Laboratory and Clinical Medicine, 142(3), 172-177.

30.Moreno M. I. N., Isla M. I., Sampietro A. R., Vattuone, M. A. (2000). Comparison of the free radical-scavenging activity of propolis from 
several regions of Argentina. Journal of ethnopharmacology, 71(1), 109-114.

31.Isla M. I., Moreno M. N., Sampietro A. R., Vattuone, M. A. (2001). Antioxidant activity of Argentine propolis extracts. Journal of Ethnopharmacology, 76(2), 165-170.

32.Koksel O., Ozdulger A., Tamer L., Cinel L., Ercil M., Degirmenci U., Kanik, A. (2006). Effects of caffeic acid phenethyl ester on lipopolysaccharide-induced lung injury in rats. Pulmonary pharmacology \& therapeutics, 19(2), 90-95.

33.Hoşnuter M., Gürel A., Babucçu O., Armutcu F., Kargi E., Işikdemir A. (2004). The effect of CAPE on lipid peroxidation and nitric oxide levels in the plasma of rats following thermal injury. Burns, 30(2), 121-125.
34.Di Carlo G., Mascolo N., Izzo A. A., Capasso, F. (1999). Flavonoids: old and new aspects of a class of natural therapeutic drugs. Life sciences, 65(4), 337-353.

\section{Corresponding Author}

\section{Ezgi AYDIN}

Cumhuriyet University,

Faculty of Dentistry,

Department of Oral and Maxillofacial Surgery,

Sivas, Turkey

Phone: +90 5065096556

E-mail: ezzgi_aydinn@hotmail.com 